\title{
The Influence of Regulated Marital Conflict Resolution Styles on Marital Stability in Kiambu County, Kenya
}

\author{
Sarah Njoroge, (MA, Marriage \& Family Therapy) \\ Machs Rapha Services, Kenya
}

Doi: 10.19044/esj.2017.v13n29p240 URL:http://dx.doi.org/10.19044/esj.2017.v13n29p240

\begin{abstract}
The purpose of the study was to establish the relationship between regulated conflict resolution styles and marital stability in Kiambu County, Kenya. Specifically, the study sought to: establish the types of marital conflicts among married individuals in Kiambu $\mathrm{C} \backsim$ unty; determine the various marital conflict resolution styles used by married individuals in the $\mathrm{C} \square$ unty, and; e tabli $t \mathrm{~h}$ the relati $\square$ hhip between marital $\mathrm{c} \square$ nflict re $\square$ luti $\square$ n styles and marital stability. Descriptive-correlation research design was used. Data was collected from 96 married individuals aged 18 years and above by aid of a structured questionnaire. Data analysis was carried out using SPSS. The statistical techniques applied included independent samples T-test, Chisquare and Mann-Whitney $U$ test. The results showed that most types of conflicts were solvable. Descriptive statistics indicated that regulated marital conflict resolution styles were used by majority of the respondents, with validating styles being the most applied $(\mathrm{M}=2.87, \mathrm{SD}=0.745)$. This was followed by volatile styles $(\mathrm{M}=2.79, \mathrm{SD}=0.827)$ and avoidant styles $(\mathrm{M}=2.79, \mathrm{SD}=0.739)$. The difference between individuals in stable marriages and those in unstable marriages was not statistically significant in terms of their use of regulated marital conflict resolution styles. It was concluded that regulated conflict resolution styles were a necessary but not sufficient conditions for marital stability. It was recommended that premarital counselors should highlight to the would be couples that some conflicts are perpetual and therefore require coping with, rather than resolving.
\end{abstract}

Keywords: Marital Conflict Resolution, Regulated Style, Marital Stability

\section{Introduction}

Marriage is defined herein as a union between a man and a woman who makes commitment to each other as spouse (Olson \& De frain 2013). Geok (2012) define conflict as a situation in which interdependent people 
express differences in satisfying their individual needs and interests, and experience interference from each other in accomplishing their goals. The differences in question cannot coexist without some adjustment.

According to Balswick and Balswick (2006), stable families are not those without conflicts but those which successfully manage conflict when it arises. Further, while every marriage relationship is as unique as the individuals themselves, Ashford (2006) asserts that some degree of conflict is actually necessary to keep a marriage dynamic. This therefore means that marital conflict has a positive and negative facet. Gottman (1999) associated marital stability with whether the couple would stay happily together or would lose their way in the face of conflict in the marriage. Wayas (2012) defined marital stability as firmness and strength to endure under hard as well as easy circumstances of which conflict is a major aspect.

Gottman (1999) explains marital conflict resolution styles as the different ways in which spouses can resolve their conflicts. Based on his research, Gottman (1994, p.28) concluded that a "lasting marriage results from a couple's ability to resolve the conflicts that are inevitable in any relationship". The key therefore lies in the balance between positive and negative behaviours. Couples whose positive interactions outnumber their negative interactions are known as 'regulated': marital stability is stronger when the ratio of positive to negative behaviours is at least 5:1. Those marriages where negativity prevails are labelled "non-regulated" and are more likely than regulated ones to be unhappy marriages in which separation and/or divorce is likely.

Gottman (1999) proposed that there are at least three different styles of couple conflict. These three styles are avoidant, validating, and volatile which Gottman refers to as regulated. Gotman consider these styles regulated because couples maintain a more stable and satisfying relationship. An important point that Gottman (1999) makes is the idea that one 'regulated' style is not superior to the other.

Gottman (1999) distinguish the three regulated styles by the degree to which partners attempt to influence each other through persuasion and dialogue and the timing of the influence attempts. Avoidant couples prefer to minimize conflict as much as possible by agreeing to disagree. Validating couples address conflict by emphasizing the importance of making sure each person is understood and their views are appreciated, or validated. Volatile couples are more passionate and energetic and are not afraid of lively debates and disagreements. In contrast, unregulated couples are labeled 'hostile' and participate in destructive and contemptuous conflict that undermines positive sentiment and marital stability.

Marriage today is faced with enormous challenges (Gichinga, 2003). These challenges range from economic, social, political, religious, 
psychological and emotional among others. Marital conflict resolution system that was in place by different cultures and communities is no longer existent. The Kenyan family life cycle is quickly changing just like many others the world over (Carter \& McGoldrick, 2005).

The social support systems focusing on couples and families are quickly eroding leaving the subjects with fewer alternatives for support and help. The result is the rise of divorce cases filed in courts (Makeni, 2011). Statistical data reported by Muthoni and Makana (2015) indicate that divorce cases are on the rise in Kenya, with the number of divorce cases filed at Milimani Law Courts in Nairobi alone rising steadily from 295 in the year 2005 to a total of 1,246 between the years 2010 and 2015. This suggest that marriages in Kenya today are increasingly becoming unstable.

Based on his research, Gottman (1994) concluded that a lasting marriage results from a couple's ability to resolve the conflicts that are inevitable in any relationship. Regulated conflict resolution styles have been proposed to be the most effective styles that lead to marital stability and satisfying relationship. However, empirical support for these styles are lacking in the Kenya African context where cultural influences potentially exist. Past studies undertaken by Odhiambo (2012) and Okello (2005) on marital conflict and marital conflict resolution styles/management carried out in Kenya suggest the need to understand marital conflict resolution styles in an african context.

Odhiambo (2012) carried out research on marital discord in Kenya focusing on the causes emanating from social dimensions. His findings show that traditional values and cultural practices have a great impact on marital conflicts. On the other hand, Okello (2005) carried out a research on factors influencing marital conflict among Church wedded couples in Pentecostal Churches in Masinga Division, Machakos District, Kenya. The study observed that spouses generally disregarded resolving conflict. The two studies however did not examine the relationship between conflict resolution styles and marital stability.

Empirical evidence is needed on the efficacy of the Gottman Theory within marriages in the Kenyan context in order to enhance the practice of marriage counseling and family therapy. Support for the possibilities of preventing marital discord through interventions focused on building skills in diverse conflict resolution styles is vital (Greef \& Bryune (2000).

This study sought to answer the question; are the marital conflict resolution styles of couples in the stable marriages in modern-day Kenya regulated? The purpose of the study was to establish the relationship between regulated conflict resolution styles and marital stability in Kiambu County, Kenya. This study sought to answer the following questions: 
i. What type of marital conflict exist among married individuals in Kiambu County?

ii. Which are the conflict resolution styles used by the married individuals in Kiambu County?

iii. Is there a relationship between regulated marital conflict resolution styles and marital stability?

\section{Literature Review}

Gottman (1994) propose that there are at least three different styles of conflict resolution styles that can lead to successful marital outcomes. These three styles are avoidant, validating and volatile, which Gottman calls regulated (Gottman, 1994, 1999). These styles are regulated in that couples maintain a more stable and satisfying relationship than "unregulated" styles by using strategies to disengage from destructive conflict and by engaging in positive interactions that are significantly more frequent than the negative interactions. An important point that Gottman (1999, p. 88) makes is the idea that "one regulated style is not superior to the other."

According to Gottman (1999), a validating partner listens attentively to their partner while showing support and concern. Even when discussing difficult issues, validating partners display a lot of ease and calm. It is typical of these partners to let their spouse know that they consider their opinions and emotions valid even when they don't agree with them. These couples begin their disagreements by letting each person explain their perspective on the topic. After both have been heard, the couple begins a process of trying to convince their partner of the rightness of their opinion. The discussion ends when they negotiate a compromise (Gottman, 1994b). Because their relationships emphasize mutual respect, validators pick their battles carefully. Arguments are more like problem-solving discussions. Validating partners tend to be good friends and emphasize "we"-ness in their relationship. However, sometimes validating couples turn their relationships into passionless arrangements in which romance and selfhood are sacrificed for friendship and togetherness. Couples can lose their sense of self and end up forgoing their personal development in favor of keeping the relationship strong (Gottman, 1994b). Still, these marriages seem to be solid ones. Validating has been correlated with the highest relationship satisfaction and is often the type of conflict resolution that clinicians and educators teach in classes and therapy (Kurdek, 1995).

In contrast, volatile relationships are characterized by high emotion with extreme levels of both positive and negative behaviors; however, more positive than negative behaviors still prevail. These couples see themselves as equals and work toward a relationship that highlights and strengthens individuality (Gottman, 1994a, 1994b). A volatile couple engages in what 
most people think of as a "fight." They exhibit active engagement and are not passive or withdrawn. They discuss the issue rationally and hear each other's views; and spends most of their time in a heated attempt to persuade each other to change their opinion without compromise. These couples have high emotion when they disagree, but instead of evolving into something hostile in nature, their marriage remains warm and loving. In fact, these couples are characteristic of marriages that remain passionate and exciting throughout their course (Gottman, 1994b). They, like validators, do not intentionally inflict emotional pain on one another, and their extreme negative emotions are balanced by intense positive feelings as well (Gottman 1994a, 1994b).

One risk of a volatile relationship is that if a couple loses sight of the boundaries of their relationship, they could slide into a hostile marriage (an unregulated type) and lead their relationship into self-destruction (Gottman 1994b). Volatile couples seem to enjoy playfully teasing one another, but this brand of humor can be risky. They censor few of their thoughts, and hurt feelings can inadvertently occur.

According to Gottman (1994b), an avoidant conflict resolution style is characterized by someone who will not argue for their position but instead will minimize the disagreements and agree to disagree. They are conflict minimizers and make light of their differences rather than resolve them. Perhaps one reason for this is that little gets resolved in avoidant marriages when differences are aired. In their disagreements, neither partner attempts to persuade the other and they don't seek for a compromise. Solving things in these marriages means that either they ignore the difference or one partner agrees to act more like the other. However, in the process of agreeing to disagree, they reaffirm the love and satisfaction they have in their marriage overall, and they believe that the positives outweigh the majority of issues where they disagree. They do not commonly use behaviors or words intent on hurting their partner or converting their partner to their way of thinking, and so their relationship remains regulated and relatively quiet and peaceful.

Gottman (1994b) further explains that avoidant couples tend to have calm, pleasant lives. They display little of the intense passion that volatile couples and even validating couples display. However, this creates a potential risk, as they do not know how to address a conflict should they be forced to do so someday. If an issue comes up that is too overwhelming for couples to "agree to disagree," the issue could negatively overwhelm their interaction and the marriage could suffer. Additionally, their marriages can become lonely, as partners eventually feel their spouse doesn't really understand them because talk about disagreements is always shut down. 


\section{Methodology}

This study used both descriptive survey research design as well as a correlational research design. The study was conducted in Muchatha Ward, Kiambu County, located in the Central region of Kenya. The County is largely inhabited by the Kikuyu community. However there are other communities residing in the County especially civil servants working in public offices, personnel working in the banking sector and in institution of learning. There are also members from other communities who are married in the County as well as those residing in the County but working in Nairobi due to the County's close proximity to the city. This enriched the study by providing varied ethnic study population with a range of social-cultural and economic backgrounds. Kiambu County was chosen as the location of the study because it makes up some of the worst hit Counties where domestic violence is rampant and the trend of cases reported is increasing according to economic survey reports (Mucheru, 2014).

The target population was drawn from Muchatha Ward which had a total of 4,033 households as per data from the year 2009 census (Kenya National Bureau of Statistics, 2009). The inclusion criteria was indiviuals who had been legally married as per the Marriage Act (2014) of Kenya. A purposive sample of 96 individuals whose marriage had lasted for at least one year was selected.

A questionnaire was used as the research instrument. The questionnaire comprised of a modified Marital Conflict Resolution Styles Scale (MCRSS) to assess the marital conflict resolution styles applied by the married indiviuals. A modified Marital Status Inventory (MSI) was also part of the questionnaire to measure the stability or status of the marital relationship. The MSI was thought to be a Gottman-type measure of progression along a continuum, with no thoughts of divorce on one extreme and filing for or being divorced on the other. The questions are presented in true-false format and inquire into specific thoughts and behaviors believed to represent progressive steps toward divorce. Thus, scores ranged from 0 to 10 , with higher scores representating greater marital instability. The MCRSS was derived from the Thomas-Kilmann Conflict Mode Instrument to determine whether the married individuals preferred to use any one of the following types of conflict resolution modes: competing, collaborating, compromising, avoiding and accommodating (Thomas \& Kilmann, 2007).

Reliability of the instrument was determined by calculating the reliability coefficient which often assumes a value from zero to +1.00 (Lodico, Spaulding \& Voegtle, 2010). Cronbach's alpha, which measures internal consistency based on inter-tem correlation was determined. The instrument was considered reliable because it exceeded Cronbach's Alpha of 
0.7 threshold. Data was collected from respondents through face-to-face approach.

The process of analyzing data entailed coding and entering data into the Statistical Package for the Social Sciences (SPSS). The data was then analyzed using descriptive statistics which entail computation of the mean, standard deviation and percentage frequencies of the dataset. Chi-square test was run to determine whether marital stability varied by respondents' demographics such as gender, level of education and type of marriage. Mann Witney $U$-test was used to compare mean scores between respondents in stable marriages and those in unstable marriages.

\section{Findings and Discussions}

Out of the 96 questionnaires administered, 76 were successfully filled. This translates to $79 \%$ response rate. Rubin and Babbie suggest that "a response rate of at least $50 \%$ is usually considered adequate for analysis and reporting; a response rate of at least $60 \%$ is good; and a response rate of $70 \%$ is very good" (Rubin \& Babbie, 2009, p117). Therefore, response rate in this was more than adequate to undertake analysis.

The study sought to establish respondents' use of validating conflict resolution styles. The styles were scored on a 4-point scale. The findings are shown in Table 1.

Table 1 Use of Validating Conflict Resolution Styles

\begin{tabular}{ccc}
\hline Validating conflict resolution styles & Mean & $\begin{array}{c}\text { Standard } \\
\text { Deviation }\end{array}$ \\
\hline I tell him/her my ideas and ask for his/hers. & 0.550 \\
I try not to hurt the other's feelings. & 3.13 & 0.663 \\
person. & 2.99 & 0.822 \\
I sometimes sacrifice my own wishes for the wishes of the other & 2.93 & 0.789 \\
I always share the problem with the other person so that we can work & 2.76 & 0.901 \\
Rather than negotiate the things on which we disagree, I try to stress \\
those things upon which we both agree. \\
Overall mean score
\end{tabular}

Table 1 shows that top in the list of validating conflict resolution styles used by the respondents was to tell him/her his/her ideas and ask for his/hers $(\mathrm{M}=3.13, \mathrm{SD}=0.550)$; followed by trying not to hurt the other's feelings $(M=2.99, S D=0.663)$ and sometimes sacrificing own wishes for the wishes of the partner $(\mathrm{M}=2.93, \mathrm{SD}=0.822)$. Respondents also always shared the problem with the other person so that it can be worked out (2.53, $\mathrm{SD}=0.901)$ as well as tried to stress those things on which they both agreed rather than negotiate the things on which they disagreed $(M=2.53$, $\mathrm{SD}=0.901)$. The overall meanscore on the use of validating conflict resolution styles was 2.87 on a 4-point scale, which suggests that validating conflict resolution styles was applied by respondents in the study to resolve 
their marital conflicts. This agrees with Gottman's (1999) distinction of the regulated conflict resolution styles and his description of validating styles.

The study also sought to determine whether respondents used avoidant conflict resolution styles to resolve conflict in their marriage. Table 2 shows that the most practiced avoidant style was: trying to do what is necessary to avoid useless tensions $(\mathrm{M}=3.09, \mathrm{SD}=0.593)$ followed by trying to soothe the other's feelings and preserve the relationship $(\mathrm{M}=3.04,0.756)$ and trying to avoid creating unpleasantness $(\mathrm{M}=2.89,0.723)$. The table also shows that respondents sometimes avoided taking positions which would create controversy $(\mathrm{M}=2.75, \mathrm{SD}=0.695)$ and tried to postpone the issue until they have had sometime to think about it $(\mathrm{M}=2.57, \mathrm{SD}=0.854)$. However, respondents who let others take responsibility for solving the problem were the minority as implied by the least mean score on a 4-point scale $(\mathrm{M}=2.37$, $\mathrm{SD}=0.814)$.

The overall mean score on the use of avoidant conflict resolution style to resolve marital conflict as measured on a 4-point scale was high $(\mathrm{M}=2.79, \mathrm{SD}=0.739)$ suggesting that majority of the respondents used avoidant conflict resolution styles. This is in line with Gottman's (1999) theory which suggests that avoidant couples prefer to minimize conflict as much as possible.

Table 2 Use of Avoidant Conflict Resolution Styles

\begin{tabular}{ccc}
\hline Avoidant conflict resolution Styles & Mean & $\begin{array}{c}\text { Standard } \\
\text { Deviation }\end{array}$ \\
\hline I try to do what is necessary to avoid useless tensions. & 3.09 & 0.593 \\
I might try to soothe the other's feelings and preserve our & 0.756 \\
relationship. & 3.04 & 0.723 \\
I try to avoid creating unpleasantness for myself. & 2.89 & 0.695 \\
I sometimes avoid taking positions which would create controversy. & 2.75 & 0.854 \\
I try to postpone the issue until I have had some time to think about & 2.57 & 0.814 \\
it. & 2.37 & 0.739 \\
There are times when I let others take responsibility for solving the & & 2.79 \\
\hline problem. & & \\
\hline
\end{tabular}

Respondents were further asked to indicate whether they used volatile conflict resolution styles in their marriage. Table 3 shows that being firm in pursuing own goals was the most prevalent practice yielding the highest mean score on a 4 point scale $(\mathrm{M}=2.92, \mathrm{SD}=0.786)$. The practice of always trying to find a compromise solution was reported by majority of the respondents as indicated by a relatively high mean score on a 4 point scale $(\mathrm{M}=2.84, \mathrm{SD}=0.634)$. A similar mean score was established for letting another have some of their positions if they were let to have theirs (2.84, $\mathrm{SD}=0.784$ ); and trying to show him/her the logic and benefits of own position ( $\mathrm{M}=2.84, \mathrm{SD}=0.954)$. The least practiced volatile conflict resolution styles in the marriage was attempting to get all concerns/issues immediately 
out into the open. The overall mean score on a 4-point scale was high $(\mathrm{M}=2.79, \mathrm{SD}=0.827)$ which implied that respondents in the study also generally applied volatile conflict resolution styles as theorized by Gottman (1999).

Table 3 Use of Volatile Conflict Resolution Styles

\begin{tabular}{ccc}
\hline volatile conflict resolution Styles & Mean & $\begin{array}{c}\text { Standard } \\
\text { Deviation }\end{array}$ \\
\hline I am usually firm in pursuing my goals. & 2.92 & 0.876 \\
I always try to find a compromise solution. & 2.84 & 0.634 \\
some of mine. & 2.84 & 0.784 \\
I will let another have some of their positions if they lets me have & & \\
I try to show him/her the logic and benefits of my position. & 2.84 & 0.954 \\
I attempt to get all concerns and issues immediately out in the open. & 2.53 & 0.887 \\
\hline Overall mean score & 2.79 & 0.827 \\
\hline
\end{tabular}

Mann-Whitney $U$ test was performed to compare the mean ranks of avoidant conflict resolution and marital stability. The output is presented in Table 4. The table indicates that all the avoidant conflict resolution styles, except trying to postpone the issue until respondent had sometime to think about it had higher mean ranks among respondents whose marital relationship was unstable than those respondents whose marital relationship was stable. This agrees with the findings of Gottman (2004) which suggested that this type of a conflict resolution style creates a potential risk. This means that if issue arises that is too overwhelming for couples to "agree to disagree," the issue could negatively cause conflict that distabilizes their marriage. Nevertheless, the test statistics showed that this difference was not statistically significant, suggesting that there was no correlation between avoidant conflict resolution styles and marital stability of the respondents.

Table 4 Ranks of Avoidant Conflict Resolution Style and Marital Stability

\begin{tabular}{|c|c|c|c|c|}
\hline & $\begin{array}{l}\text { Distribution of } \\
\text { Respondents by } \\
\text { Marital Stability }\end{array}$ & $\mathrm{N}$ & Mean Rank & Sum of Ranks \\
\hline $\begin{array}{l}\text { There are times when I let others } \\
\text { take responsibility for solving } \\
\text { the problem. }\end{array}$ & $\begin{array}{l}\text { Unstable } \\
\text { Stable } \\
\text { Total }\end{array}$ & $\begin{array}{l}15 \\
61 \\
76\end{array}$ & $\begin{array}{l}43.33 \\
37.31\end{array}$ & $\begin{array}{c}650.00 \\
2276.00\end{array}$ \\
\hline $\begin{array}{l}\text { I might try to soothe the other's } \\
\text { feelings and preserve our } \\
\text { relationship. }\end{array}$ & $\begin{array}{l}\text { Unstable } \\
\text { Stable } \\
\text { Total }\end{array}$ & $\begin{array}{l}15 \\
61 \\
76\end{array}$ & $\begin{array}{l}43.90 \\
37.17\end{array}$ & $\begin{array}{c}658.50 \\
2267.50\end{array}$ \\
\hline $\begin{array}{l}\text { I try to do what is necessary to } \\
\text { avoid useless tensions. }\end{array}$ & $\begin{array}{l}\text { Unstable } \\
\text { Stable } \\
\text { Total }\end{array}$ & $\begin{array}{l}15 \\
61 \\
76\end{array}$ & $\begin{array}{l}42.07 \\
37.62\end{array}$ & $\begin{array}{c}631.00 \\
2295.00\end{array}$ \\
\hline $\begin{array}{l}\text { I try to avoid creating } \\
\text { unpleasantness for myself. }\end{array}$ & $\begin{array}{l}\text { Unstable } \\
\text { Stable } \\
\text { Total }\end{array}$ & $\begin{array}{l}15 \\
61 \\
76\end{array}$ & $\begin{array}{l}42.73 \\
37.46\end{array}$ & $\begin{array}{c}641.00 \\
2285.00\end{array}$ \\
\hline $\begin{array}{l}\text { I try to postpone the issue until I } \\
\text { have had some time to think }\end{array}$ & $\begin{array}{l}\text { Unstable } \\
\text { Stable }\end{array}$ & $\begin{array}{l}15 \\
61\end{array}$ & $\begin{array}{l}35.37 \\
39.27\end{array}$ & $\begin{array}{c}530.50 \\
2395.50\end{array}$ \\
\hline
\end{tabular}




\begin{tabular}{ccccc} 
about it. & Total & 76 & & \\
& & & & \\
I sometimes avoid taking & Unstable & 15 & 44.77 & 671.50 \\
positions which would create & Stable & 61 & 36.96 & 2254.50 \\
controversy. & Total & 76 & & \\
\hline
\end{tabular}

Mann-Whitney $U$ test was further run to compare the mean ranks of volatile conflict resolution styles and marital stability of the respondents. Table 5 shows that respondents in stable relationship scored higher mean ranks on their usage of conflict resolution styles such as trying to find a compromise solution, being firm in own goals and trying to show partner the logic and benefit of own position as compared to respondents who were in unstable marital relationships. However, respondents in unstable relationships scored higher mean ranks in terms of letting their partner have some of their position if they are let to have some of theirs as well as attempting to get all concerns and issues immediately out into the open. However, only the difference in the mean ranks between respondents in stable marriages and those in unstable marriages in terms of attempting to get all concerns and issues immediately out into the open was statistically significant.

Table 5 Ranks of Volatile Conflict Resolution Styles and Marital Stability

\begin{tabular}{|c|c|c|c|c|}
\hline & $\begin{array}{l}\text { Distribution of } \\
\text { Respondents by } \\
\text { Marital Stability }\end{array}$ & $\mathrm{N}$ & Mean Rank & Sum of Ranks \\
\hline $\begin{array}{l}\text { I always try to find a compromise } \\
\text { solution. }\end{array}$ & $\begin{array}{l}\text { Unstable } \\
\text { Stable } \\
\text { Total }\end{array}$ & $\begin{array}{l}15 \\
61 \\
76\end{array}$ & $\begin{array}{l}33.47 \\
39.74\end{array}$ & $\begin{array}{l}502.00 \\
2424.00\end{array}$ \\
\hline $\begin{array}{l}\text { I am usually firm in pursuing my } \\
\text { goals. }\end{array}$ & $\begin{array}{l}\text { Unstable } \\
\text { Stable } \\
\text { Total }\end{array}$ & $\begin{array}{l}15 \\
61 \\
76\end{array}$ & $\begin{array}{l}37.27 \\
38.80\end{array}$ & $\begin{array}{c}559.00 \\
2367.00\end{array}$ \\
\hline $\begin{array}{c}\text { I attempt to get all concerns and } \\
\text { issues immediately out in the } \\
\text { open. }\end{array}$ & $\begin{array}{l}\text { Unstable } \\
\text { Stable } \\
\text { Total }\end{array}$ & $\begin{array}{l}15 \\
61 \\
76\end{array}$ & $\begin{array}{l}48.17 \\
36.12\end{array}$ & $\begin{array}{c}722.50 \\
2203.50\end{array}$ \\
\hline $\begin{array}{l}\text { I will let another have some of } \\
\text { their positions if they lets me } \\
\text { have some of mine. }\end{array}$ & $\begin{array}{l}\text { Unstable } \\
\text { Stable } \\
\text { Total }\end{array}$ & $\begin{array}{l}15 \\
61 \\
76\end{array}$ & $\begin{array}{l}39.93 \\
38.15\end{array}$ & $\begin{array}{c}599.00 \\
2327.00\end{array}$ \\
\hline $\begin{array}{l}\text { I try to show him/her the logic } \\
\text { and benefits of my position. }\end{array}$ & $\begin{array}{l}\text { Unstable } \\
\text { Stable } \\
\text { Total }\end{array}$ & $\begin{array}{l}15 \\
61 \\
76\end{array}$ & $\begin{array}{l}38.47 \\
38.51\end{array}$ & $\begin{array}{c}577.00 \\
2349.00\end{array}$ \\
\hline
\end{tabular}

The results of Mann-Whitney $U$ test comparing mean ranks of validating conflict resolutions and marital stability is shown in Table 6. The table shows that the use of validating conflict resolution styles such as trying to stress those things upon which they agree rather than negotiate the things on which they disagree had higher mean ranks for respondents in stable 
relationship than those in unstable marital relationship. The same to respondents who tell their his/her ideas and ask for his/hers. However, respondents in unstable marriages scored higher mean ranks in terms of sacrificing their own wishes for the wishes of their partner, trying not to hurt the other person's feelings and always sharing the problem with the other person so that it can be worked out.The test statistics revealed that the differences between the mean ranks were however not statistically significant.

Table 6 Ranks of Validating Conflict Resolution Styles and Marital Stability

\begin{tabular}{|c|c|c|c|c|}
\hline & $\begin{array}{l}\text { Distribution of } \\
\text { Respondents by } \\
\text { Marital Stability }\end{array}$ & $\mathrm{N}$ & Mean Rank & Sum of Ranks \\
\hline \multirow{3}{*}{$\begin{array}{l}\text { Rather than negotiate the things } \\
\text { on which we disagree, I try to } \\
\text { stress those things upon which } \\
\text { we both agree. }\end{array}$} & Unstable & 15 & 35.27 & 529.00 \\
\hline & Stable & 61 & 39.30 & 2397.00 \\
\hline & Total & 76 & & \\
\hline \multirow{3}{*}{$\begin{array}{l}\text { I sometimes sacrifice my own } \\
\text { wishes for the wishes of the other } \\
\text { person. }\end{array}$} & Unstable & 15 & 42.27 & 634.00 \\
\hline & Stable & 61 & 37.57 & 2292.00 \\
\hline & Total & 76 & & \\
\hline \multirow{3}{*}{$\begin{array}{l}\text { I tell him/her my ideas and ask } \\
\text { for his/hers. }\end{array}$} & Unstable & 15 & 35.80 & 537.00 \\
\hline & Stable & 61 & 39.16 & 2389.00 \\
\hline & Total & 76 & & \\
\hline \multirow{3}{*}{$\begin{array}{l}\text { I try not to hurt the other's } \\
\text { feelings. }\end{array}$} & Unstable & 15 & 37.83 & 567.50 \\
\hline & Stable & 61 & 38.66 & 2358.50 \\
\hline & Total & 76 & & \\
\hline \multirow{3}{*}{$\begin{array}{l}\text { I always share the problem with } \\
\text { the other person so that we can } \\
\text { work it out }\end{array}$} & Unstable & 15 & 41.37 & 620.50 \\
\hline & Stable & 61 & 37.80 & 2305.50 \\
\hline & Total & 76 & & \\
\hline
\end{tabular}

Chi-square test was run to determine whether the relationship between level of education and marital stability shown in Table 7 was statistically significant. The relationship was found to be statistically significant $X^{2}(3)=12.123, p<.05$.

Table 7 Chi-Square Tests of Level of Education and Marital Stability

\begin{tabular}{cccc}
\hline & Value & Df & Asymp. Sig. (2-sided) \\
\hline Pearson Chi-Square & 12.123 & 3 & .007 \\
Likelihood Ratio & 10.685 & 3 & .014 \\
Linear-by-Linear Association & 10.468 & 1 & .001 \\
N of Valid Cases & 76 & & \\
\hline
\end{tabular}

A chi-squate test was run to determine if a relationship existed between type of marriage and marital stability. Table 8 shows the chi-square tests. The table indicates that the relationship between type of marriage and marital stability was statistically significant, $\mathrm{X}^{2}(4)=15.612, p<.05$. This suggest that the type of marriage had an influence on marital stability. Given 
that Christian marriages were the most stable, it is possible that the values espoused by Christian couples played a role in influencing the stability of their marriages. This agrees with a previous study in Kenya by Odhiambo (2012) which showed that values and cultural practices have a great impact on marital conflicts within his study area. It also agrees with a study by Birditt et al., that couples who cohabited before marriage had higher rates of divorce.

Table 8 Chi-Square Tests of Type of Marriage and Marital Stability

\begin{tabular}{cccc}
\hline & Value & df & Asymp. Sig. (2-sided) \\
\hline Pearson Chi-Square & 15.612 & 4 & .004 \\
Likelihood Ratio & 14.991 & 4 & .005 \\
Linear-by-Linear Association & 1.528 & 1 & .216 \\
N of Valid Cases & 76 & & \\
\hline
\end{tabular}

\section{Conclusion}

Most types of marital conflicts experienced by married individuals in Kiambu County were solvable. Such conflicts included dealing with important life changes such as the birth of a child, a job loss, illness or death of a loved one; handling of major issues about the children including whether or not to have a child; handling major issues and events concerning in-laws and relatives; occurance of disturbing events such as violence, drugs or an affair and trouble handling financial issues. Perpetual conflicts mainly presented in form of spillover of non-marital stress such as job tension into the marriage and the occurance of unpleasant fights in the marriage.

Married individuals in Kiambu County used all the three regulated conflict resolution styles to resolve conflict in their marriages. Among validating conflict resolution styles which were highly used, sharing of ideas topped the list, along with trying not to hurt the partner's feelings and sacrificing own wishes for the wishes of the partner. In terms of avoidant styles, doing what is necessary to avoid useless tensions was the most manifest, followed by trying to soothe the partner to preserve the relationship and trying to avoid creating unpleasantness. Of the volatile conflict resolution styles, firmness in pursuing own goals was the most manifest, followed trying to find a compromise solution and letting the partner have some of their position in a give and take way.

Regulated conflict resolution styles were a necessary but not sufficient conditions for marital stability. The three regulated conflict resolution styles potentially had a positive influence on marital stability as depicted by the higher ratio of married individuals in stable marriages to those in unstable relationships. However, in terms of statistical significance, the individual contribution of each regulated conflict resolution styles to marital stability was small. The only exception was the attempt by married individuals to get all concerns and issues immediately out into the open, 
which fall under the volatile conflict resolution style. Instead, sociodemographic factors especially level of education and type of marriage had a stronger influence on marital stability.

In view of the conclusions, it is recommended that premarital counselors should highlight to would be couples that some conflicts, if not most conflict, are perpetual and therefore require coping with, rather than resolving. Thus, early identification and classification of the same in the marital life of individuals would go a long way in maintaining a stable marriage.

The adoption of regulated marital conflict resolution styles should be complemented by the seven factors that build strong marriages as proposed by Gottman (1999) in what he calls “The Sound Relationship House". These are: creating shared meaning, making life dreams come true, dialogue for perpetual problems, maintaining a positive mental attitude, turning towards the spouse through building emotional bank accounts, sharing fondness and admiration and knowing one another.

\section{References:}

1. Ashford, J. B. (2006). Human Behavior in the Social Environment: Multidimensional perspective (3rd edition). California: Thompsons Brooks.

2. Balswick, Jack O. \&Balswick, J. K. (2006). A Model for Marriage. Downers Groove: Intervarsity Press.

3. Carter, B. \& McGoldrick, M. (2005).The expanded family life cycle: Individual, family and social perspectives. Boston: Pearson-Allyn\& Bacon

4. Geok, L. S. (2012). A study of marital conflict on measures of social support and mental health. Sunway Academic Journal, 90-104.

5. Gichinga, E. (2003). Premarital Counseling: A guide to the counselor. Nairobi: Gem Counseling services.

6. Gottman, J. (1994a). Why Marriages Succeed or Fail: And How You can Make Yours Last. New York: Simon \& Schuter.

7. Gottman, J. M. \& Silver, N. (1999). The seven principle for making marriages work: NewYork: New Crown Publishers.

8. Gottman, J. M. (1994b). What Predicts Divorce?: The Relationship Between Marital Processes and Marital outcomes. New York: Lawrence Elbaum Associates.

9. Gottman, J. M. (1999). The Seven Principles for Making Marriage Work. New York: Three Rivers Press.

10. Greeff, A.P. \& De Bruyne, T. (2000). Conflict management style and marital satisfaction. Journal of Sex \& Marital Therapy, 26(4), 321334 
11. Kenya National Bureau of Statistics (2009). Population of Housing Censuses. Nairobi: Kenya National Bureau of Statistics.

12. Kurdek, L. A. (1995). Predicting change in marital satisfaction from husbands' and wives' conflict resolution styles. Journal of Marriage and Family, 57(1), 153-164.

13. Lodico, M. G., Spaulding, D. T. \& Voegtle, K. H. (2010). Methods in Educational Research: From Theory to Practice. New York: John Wiley \& Sons.

14. Makeni, J. (2011). Kenya divorce rate soars but high legal fees keeps couples in check. Retrieved on January 23, 2015 from http://www.nation.co.ke

15. Mucheru, E. N. (2014). Social Factors Influencing Boy Child Perception on Gender Based Violence on Day Secondary Schools in Kiambu District, Kiambu County, Kenya. Retrieved on $5^{\text {th }}$ October 2015 from http://eap.uonbi.ac.ke

16. Muthoni, K. \& Makana, F. (2015). Revealed: Secrets behind Divorce Cases in Kenya. Retrieved on $17^{\text {th }}$ September from http://www.standardmedia.co.ke

17. Odhiambo, S. (2012). Social dimensions of marital conflict in kenya. Journal of Power, Politics \& Governance, 1(1), 34-45.

18. Okello, O. M. (2012). Factors influencing marital conflicts among church wedded couples in pentecostal churches in Masinga Division, Machakos, District. Retrieved on $10^{\text {th }}$ August 2015 from irlibrary.ku.ac.ke/handle/123456789/9829

19. Olson, D.H. \& DeFrain J. (2013) Marriages and families. McGraw Hill.New York.

20. Rubin, A. \& Babbie, E. (2009). Essential Research Methods for Social Work. New York: Cengage Learning.

21. Thomas, K. W., \& Kilmann, R. H. (2007). Thomas Kilmann Conflict Mode Instrument. Mountain View, CA: CPP, Inc.

22. Wayas, S. O. (2012). Communication, suspicion and stability in marriage: examples from the experiences of married women in two private Universities in Ogun State, Nigeria. Department of Human Resource 